\title{
[5.
}

\section{Anti-inflammatory Effect of cream and ointment from 2,5- bis- (4- Nitrobenzilidine) cyclopentanoneagainst Edema in Mice Induced by Formalin}

\section{Efek Antiinflamasi Sediaan Krim dan Salep Senyawa2,5-Bis-(4- Nitrobenzilidin) Siklopentanonpada Edema Mencit yang Diinduksi Formalin}

\author{
Paulina Maya $0 .^{1 *}$ dan Fransiska Ayuningtyas $\mathrm{W}^{2}$ \\ 1 Akademi Farmasi Theresiana Semarang, \\ 2 Akademi Analis Kesehatan Theresiana Semarang \\ *email korespondensi: paulinamaya2811@ gmail.com
}

\begin{abstract}
Creams-and ointments are topical dosage forms used in the manufacture of drugs. Topical anti-inflammatory drug is a solution to problems of gastrointestinal side effects caused by taking nonsteroidal anti-inflammatory drug orally. The compound 2,5-bis (4-nitrobenzilidine) cyclopentanone is an analog of curcumin which has better antiinflammatory activity than curcumin. This study aimed to determine the antiinflammatory effect of cream and ointment from 2,5-bis (4-nitrobenzilidine) cyclopentanoneagainst edema in mice induced by formalin. This research were experimental randomized complete design using a single factor. Twenty mice were divided into 4 groups: group I were given a cream base, the group II were given ointment base, group III were given cream compound $0.25 \%$ and group IV were given ointment compound $0.25 \%$. The data were processed into AUC values and the percentage of anti-inflammatory effectwere calculated. Results were analyzed using ANOVA and T-test statistics. The results showed that between the dosage form had statistically difference of anti-inflammatory effect $(p<0.05)$. The ointmentshowed a greater value of antiinflammatory activity rather than cream.
\end{abstract}

Keywords:2,5- bis- (4-Nitrobenzilidine) cyclopentanone, cream, ointment, antiinflammatory

Abstrak: Krim dan salep merupakan bentuk sediaan topikal yang digunakan dalam pembuatan obat. Obat antiinflamasi topical merupakan solusi bagi permasalahan efeksamping gastrointestinal yang diakibatkan oleh obat antiinflamasi non steroid secara per oral. Senyawa 2,5-bis-(4-nitrobenzilidin) siklopentanon merupakan analog kurkumin yang memiliki aktivitas antiinflamasi lebih baik dibandingkan kurkumin. Oleh karenaitu, penelitian ini bertujuan untuk mengetahui pengaruh bentuk sediaan terhadap efek 
antiinflamasi topical senyawa 2,5-bis-(4-nitrobenzilidin) siklopentanon pada mencit galur Swiss yang diinduksi formalin. Penelitian ini merupakan penelitian eksperimental murni dengan rancangan acak lengkap menggunakan satu faktor. Sejumlah 20 mencit dibagi menjadi 4 kelompok, yaitu kelompok I merupakan mencit yang diberikan basis krim, kelompok II merupakan mencit yang diberikan basis salep, kelompok III merupakan mencit yang diberikan krim 2,5-bis-(4-nitrobenzilidin) siklopentanon $0.25 \%$ dan kelompok IV merupakan mencit yang diberikan salep 2,5-bis-(4-nitrobenzilidin) siklopentanon $0.25 \%$. Data diolah menjadi nilai AUC dan dihitung persentase daya antiinflamasi. Hasil dianalisis menggunakan statistik ANOVA dan T-test. Hasil penelitian menunjukkan bahwa perbedaan bentuk sediaan berpengaruh terhadap daya antiinflamasi $(\mathrm{p}<0.05)$. Persentase daya antiinflamasi salep 2,5-bis-(4-nitrobenzilidin) siklopentanon memiliki nilai lebih besar dibandingkan bentuk sediaan krim.

Kata kunci: senyawa 2,5-bis-(4-nitrobenzilidin) siklopentanon, krim, salep, antiinflamasi

\section{Pendahuluan}

Inflamasi merupakan respon reflektif tubuh terhadap infeksi, ikatan antibodi terhadap antigen di dalam tubuh, iritasi mekanik, atau luka dan kerusakan jaringan (Rhen dan Cidlowski, 2005). Beberapa gejala yang dapat dikenali dalam proses inflamasi antara lain adanya rubor (kemerahan), edema (pembengkakan), kolor (panas), dolor (nyeri), dan functio laesa (hilangnya fungsi). Gejala tersebut muncul akibat pelepasan mediator inflamasi seperti histamin, serotonin, bradikinin, prostaglandin, dan leukotrien yang menimbulkan reaksi radang (Katzung, 2002).

Pengobatan inflamasi dilakukan dengan mengkonsumsi obat-obat antiinflamasi yang bekerja dengan cara menghambat pelepasan prostaglandin ke jaringan yang cidera. Akan tetapi, obat golongan non steroid (AINS) memiliki efek samping yang dapat mengiritasi lambung (Kee dan Hayes, 1996). Berdasarkan efek samping yang ditimbulkan, perlu dilakukan penggantian rute pemberian obat melalui topikal. Pemberian obat secara topikal dapat meningkatkan bioavaibilitas dan efikasi obat dengan menghindari first-pass elimination pada hati (Gunani, 2009).Keuntungan efek lokal yang diinginkan juga dapat dicapai dengan penggunaan obat antiinflamasi topikal. Keefektifan obat secara sistemik dari pengobatan secara topikal bergantung pada kemampuan penetrasi obat ke dalam kulit serta kemampuan untuk memasuki sirkulasi atau diabsorbsi ke dalam jaringan yang lebih dalam untuk menghambat siklooksigenase.

Kurkumin merupakan senyawa aktif yang memiliki berbagai aktivitas yaitu sebagai antivirus, antijamur (Araujo dan Leon, 2001), antioksidan (Jayaprakasha dkk., 2006), antikanker (Anand dkk., 2008), antibiotik, antiseptik (Pandey dan Sanjay, 2010), antiinflamasi, antidiabetes, antikoagulan dan antiaging (Niazi dkk., 2010). Kurkumin mempunyai efek antiinflamasi yang dapat diterapkan secara topikal untuk melawan peradangan, iritasi, dan alergi pada kulit yang terkait dengan kondisi inflamasi (Chainani-Wu, 2003). Kurkumin memiliki gugus metilen aktif yang menyebabkan tidak stabil pada $\mathrm{pH}$ basa dan cahaya sehingga mudah terdegradasi. Oleh karena itu perlu dilakukan peningkatan stabilitas kurkumin dengan memodifikasi gugus-gugus pada rantai tengah, rantai samping serta pada rantai aromatiknya (Robinson dkk., 2003). Salah satu turunan kurkumin yang dapat disintesis adalah 2,5-bis-(4-nitrobenzilidin) siklopentanon 
dengan mereaksikan 4-nitrobenzaldehid dan siklopentanon dalam suasana asam dengan menggunakan katalisator $\mathrm{HCl}$ (Widyastani dan Hariono, 2013).

Efektivitas antiinflamasi suatu obat dipengaruhi oleh berbagai faktor, yaitu in vivo, manufacturing factors, dan metode aplikasi obat. Sistem penghantaran obat merupakan salah satu faktor yang berperan dalam menentukan kecepatan laju absorbsi dan bioavailibilitas obat. Obat yang diberikan secara transdermal akan terpenetrasi melalui stratum korneum ke sirkulasi darah melalui difusi pasif (Gunani, 2009). Kemampuan penetrasi obat dipengaruhi oleh konsentrasi obat terlarut, koefisien partisi antara kulit dan bahan pembawa, dan koefisien difusi. Pemilihan bahan pembawa akan menentukan besaran koefisien partisi dan koefisien difusi (Martin dkk, 1993). Oleh karena itu, penelitian ini bertujuan untuk mengetahui pengaruh perbedaan bentuk sediaan obat terhadap efek antiinflamasi senyawa 2,5-bis-(4-nitrobenzilidin) siklopentanon terhadap edema mencit yang diinduksi formalin $0,5 \%$.

\section{Bahan dan Metode}

Penelitian ini merupakan penelitian eksperimental murni dengan rancangan acak lengkap menggunakan satu faktor. Penelitian ini dilakukan di Laboratorium Teknologi Farmasi dan Farmakologi Akademi Farmasi Theresiana Semarang. Penelitian ini menggunakan beberapa alat dan bahan yang disesuaikan dengan tahapan penelitian ini berlangsung.

\section{$2.1 \quad$ Alat}

Uji identifikasi senyawa: pipa kapiler (Nesco), lampu UV (Sterilight), oven (Binder) dan seperangkat alat gelas (Pyrex). Uji antiinflamasi: jangka sorong (Tringle Brand), spuit injeksi per oral (Terumo), needle (Terumo), stopwatch (Casio), timbangan mencit (Kern), alat-alat gelas (Pyrex), kandang pengamatan, mencit jantan galur Swiss umur 2-3 bulan dengan berat badan 2030 gram.

\subsection{Bahan}

Uji identifikasi senyawa: 4-nitrobenzaldehid (Merck), Siklopentanon (Merck), Kloroform, Etanol, Silika gel $\mathrm{GF}_{254}$ (Merck), dan akuades. Uji antiinflamasi: 2,5-bis-(4-nitrobenzilidin) siklopentanon, formalin $0,5 \%$, etanol, setaseum (basis krim), vaselin flavum (basis salep), dan CMC-Na.

\subsection{Jalannya Penelitian}

\subsubsection{Uji Identifikasi Senyawa Sintesis}

Kemurnian hasil sintesis senyawa 2,5-bis-(4-nitrobenzilidin) siklopentanon diidentifikasi dengan Kromatografi Lapis Tipis (KLT) yang diamati di bawah sinar UV 254 dengan 4- 
nitrobenzaldehid sebagai baku pembanding menggunakan fase diam silika gel $\mathrm{GF}_{254}$ dan fase gerak kloroform : etanol (99:1).

\subsubsection{Orientasi Waktu Pengolesan Tebal Edema}

Sebanyak 5 ekor mencit jantan galur Swiss diinduksi larutan formalin 0,5\%. Masing-masing telapak kaki kanan mencit disuntik formalin $0,5 \%$ sebanyak $0,025 \mathrm{~mL}$ secara subplantar, kemudian dilakukan pengukuran diameter edema yang terjadi selama empat jam pengamatan menggunakan jangka sorong.

\subsubsection{Uji Pengaruh Bentuk Sediaan Terhadap Efek Antiinflamasi}

Sejumlah 20 mencit galur Swiss diadaptasikan selama 7 hari dan dipuasakan selama $18-24$ jam. Kedua puluh ekor mencit diambil secara acak dan dibagi dalam 4 kelompok, yaitu kelompok I merupakan mencit yang diberikan basis krim, kelompok II merupakan mencit yang diberikan basis salep, kelompok III merupakan mencit yang diberikan krim 2,5-bis-(4nitrobenzilidin) siklopentanon $0.25 \%$ dan kelompok IV merupakan mencit yang diberikan salep 2,5-bis-(4-nitrobenzilidin) siklopentanon 0.25\%. Data selisih diameter edema diolah menjadi nilai AUC dan dihitung persentase daya antiinflamasi (Octasari dan Djunarko, 2012).

\subsubsection{Analisis Hasil}

Data selisih tebal edema telapak kaki kanan mencit digunakan untuk menghitung nilai AUC. Hasil perhitungan rata-rata nilai AUC pada tiap perlakuan digunakan untuk menghitung persentase daya antiinflamasi yang dianalisis secara statistik.

\section{Hasil dan Pembahasan}

\subsection{Uji Identifikasi Senyawa Sintesis}

Senyawa 2,5-bis-(4-nitrobenzilidin) siklopentanon berupa serbuk berwarna kuning kecoklatan, tidak berbau serta memiliki $\mathrm{pH}$ netral $(\mathrm{pH}=7)$.Pada silica gel $\mathrm{GF}_{254}$, senyawa 4-nitrobenzaldehid memadamkan fluoresensi di bawah sinar UV 254, sehingga bercak mudah dideteksi. Fase gerak yang digunakan adalah campuran pelarut kloroform : etanol (99:1). Kloroform bersifat non polar mampu menarik senyawa hasil sintesis yang juga bersifat non polar untuk merambat naik mengikuti pelarut yang digunakan. Senyawa 4-nitrobenzaldehid sebagai bakupembanding bersifat semi polar sehingga jarak rambat naik dari senyawa 4-nitrobenzaldehid akan lebih pendek bila dibandingkan dengan hasil sintesis senyawa 2,5-bis-(4-nitrobenzilidin) siklopentanon.

Identifikasi KLT pada reaksi antara 4-nitrobenzaldehid dan siklopentanon menggunakan katalisator $\mathrm{HCl}$ menunjukkan adanya bercak noda yang muncul pada fase diam. Bercak noda tunggal yang timbul pada fase diam menunjukkan bahwa hasil sintesis menghasilkan senyawa 
yang murni. Berdasarkan nilai $\mathrm{R}_{f}$ dari baku pembanding diperoleh nilai 0,8625 sedangkan nilai $\mathrm{R}_{f}$ dari senyawa hasil sintesis diperoleh nilai 0,875 .

\subsection{Orientasi Waktu Pengolesan pada Tebal Edema}

Inflamasi ditandai dengan terbentuknya edema pada telapak kaki mencit yang diinduksi formalin 0,5\% sebanyak 0,025 mL secara subplantar (Octasari dan Djunarko, 2012). Hasil orientasi berdasarkan hasil analisis paired $t$-test terjadi perbedaan tebal edema yang signifikan $\mathrm{p}(<0,05)$ pada menit ke-30 dan menit ke-80 selama 4 jam pengamatan. Pada menit ke-30 terjadi peningkatan edema yang signifikan, hal tersebut sesuai dengan Canon dkk., (2007) yang mengatakan bahwa peningkatan edema secara signifikan terjadi pada menit ke-30 yang diinduksi formalin secara subplantar. Pada menit ke-80 terjadi penurunan signifikan pada edema telapak kaki mencit yang merupakan respon eliminasi dari hewan uji.

\subsection{Uji Pengaruh Bentuk Sediaan Terhadap Efek Antiinflamasi}

Selisih nilai edema telapak kaki kanan mencit digunakan untuk menghitung nilai AUC dari masing-masing perlakuan kemudian dilanjutkan untuk menghitung persentase daya antiinflamasi dari masing - masing perlakuan. Nilai AUC pada penelitian ini digunakan untuk menentukan kemampuan senyawa uji untuk menurunkan edema. Pengolahan data nilai AUC dengan menggunakan statistik menunjukkan sebaran data tersebut normal $(p>0,05)$ dan tidak homogen ( $\mathrm{p}<0,05)$. Bila sebaran normal dan varian berbeda maka pengolahan data AUC dilanjutkan dengan menggunakan metode One Way Anova dengan post hoc Tamhane's (Sopiyudin, 2014). Berdasarkan analisis statistik menggunakan metode tersebut, maka didapatkan hasil analisis yang disajikan pada tabel I.

Pada tabel I menunjukkan nilai AUC masing - masing kelompok. Hasil uji statistik menunjukkan bahwa kelompok senyawa uji baik salep maupun krim berbeda signifikan dengan kelompok kontrol negatif masing - masing kelompok. Hal ini menunjukkan bahwa senyawa uji dengan konsentrasi 0,25\% memiliki efek antiinflamasi pada edema mencit yang diinduksi formalin $0,5 \%$. Tabel I juga menunjukkan bahwa kedua basis sediaan, basis salep maupun basis krim tidak menunjukkan adanya perbedaan yang signifikan satu dengan yang lain. Dengan demikian dapat disimpulkan bahwa kedua basis tidak memiliki efek antiinflamasi.

Tabel I. Hasil Analisis Nilai Rata-Rata AUC pada Setiap Kelompok selama 4 Jam Pengamatan

\begin{tabular}{|c|c|c|c|c|c|}
\hline \multirow{2}{*}{ Kelompok } & \multirow{2}{*}{$\begin{array}{c}\text { Rata-rata nilai AUC } \\
(\mathrm{X} \pm \text { SE) cm.menit }\end{array}$} & \multicolumn{4}{|c|}{$\begin{array}{c}\text { Hasil analisis post hoc Tamhane's } \\
\text { terhadap kelompok }\end{array}$} \\
\cline { 3 - 6 } & & I & II & III & IV \\
\hline I & $\mathbf{0 , 0 6 6 2} \pm \mathbf{0 , 0 0 3 9}$ & - & .996 & $.008 *$ & $.006 *$ \\
\hline II & $\mathbf{0 , 0 6 9 2} \pm \mathbf{0 , 0 0 3 7}$ & .996 & - & $.004 *$ & $.003 *$ \\
\hline III & $\mathbf{0 , 0 5 2 0} \pm \mathbf{0 , 0 0 4 5}$ & $.008 *$ & $.004^{*}$ & - & $\mathbf{1 . 0 0 0}$ \\
\hline IV & $\mathbf{0 , 0 3 5 8} \pm \mathbf{0 , 0 0 1 0}$ & $.006^{*}$ & $.003 *$ & 1.000 & - \\
\hline
\end{tabular}




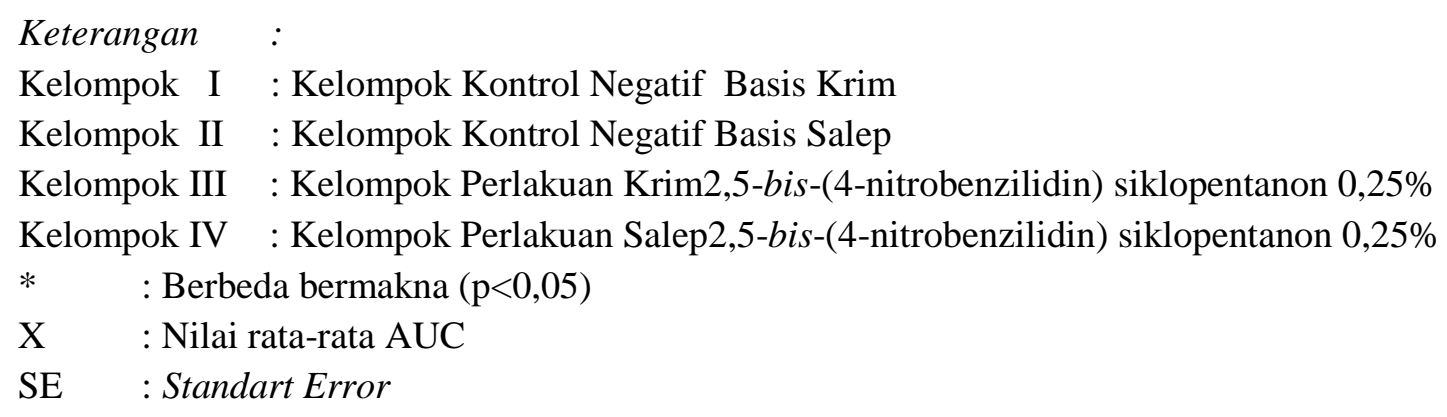

Efek antiinflamasi senyawa uji berkaitan erat dengan struktur kimia yang dimiliki. Bila dibandingkan dengan kurkumin, struktur kimia senyawa uji memiliki gugus nitro $\left(\mathrm{NO}_{2}\right)$ di posisi para yang dapat meningkatkan aktivitas antiinflamasi. Gugus nitro $\left(\mathrm{NO}_{2}\right)$ di posisi para akan menurunkan lipofilisitas dari senyawa uji dan memberikan efek elektronik sangat besar, sehingga meningkatkan interaksinya dengan reseptor (Budiati dkk, 2010). struktur kimia kurkumin memiliki gugus hidroksi $(\mathrm{OH})$ di posisi para yang dapat memberikan aktivitas antiinflamasi dengan cara mengambat enzim siklooksigenase dan lipooksigenase serta menghambat pembentukan metabolit asam arakhidonat, akan tetapi gugus metoksi $\left(\mathrm{OCH}_{3}\right)$ di posisi meta pada struktur kimia senyawa kurkumin tidak menunjukkan aktivitas antiinflamasi (Nurrochmad, 1997 dan Itokawa dkk, 2008).

Senyawa uji dan kurkumin memiliki dua cincin aromatis pada bagian (a dan c) yang dapat memberikan aktivitas antiinflamasi dengan cara menghambat biosintesis prostaglandin (Octasari dan Djunarko, 2012). Gugus metilen aktif $(\mathrm{CH} 2)$ diantara dua gugus keton yang terdapat pada struktur kimia kurkumin (bagian b) menyebabkan kurkumin tidak stabil (Tonnesen dan Karlsen, 1985). Gugus metilen aktif dapat menyebabkan kurkumin terhidrolisis dan mengalami degradasi oleh adanya pengaruh dari faktor cahaya dan $\mathrm{pH}$ basa (Tonnesen dan Karlsen, 1985; Tonnesen dkk, 1986). Modifikasi gugus diketon pada struktur kimia kurkumin menjadi analog gugus monoketon seperti pada struktur kimia senyawa uji dapat meningkatkan kestabilan senyawa uji (Robinson dkk, 2003). Oleh karena itu maka senyawa uji juga memiliki aktivitas antiinflamasi yang sama seperti kurkumin karena memiliki dua cincin aromatis pada bagian (a dan c), serta gugus nitro pada posisi para. Stabilitas dari senyawa uji juga lebih baik karena tidak memiliki gugus metilen aktif seperti pada kurkumin. $\alpha, \beta$ unsaturated pada senyawa uji dan kurkumin yang ditunjukkan dengan lingkaran warna merah membuat senyawa uji dan kurkumin menjadi rigid dan planar yang menyebabkan terjadinya delokalisasi eletron. Delokalisasi elektron yang terjadi pada senyawa uji dan kurkumin mampu meningkatkan aktivitas antiinflamasi (Majeed dkk, 1995). 


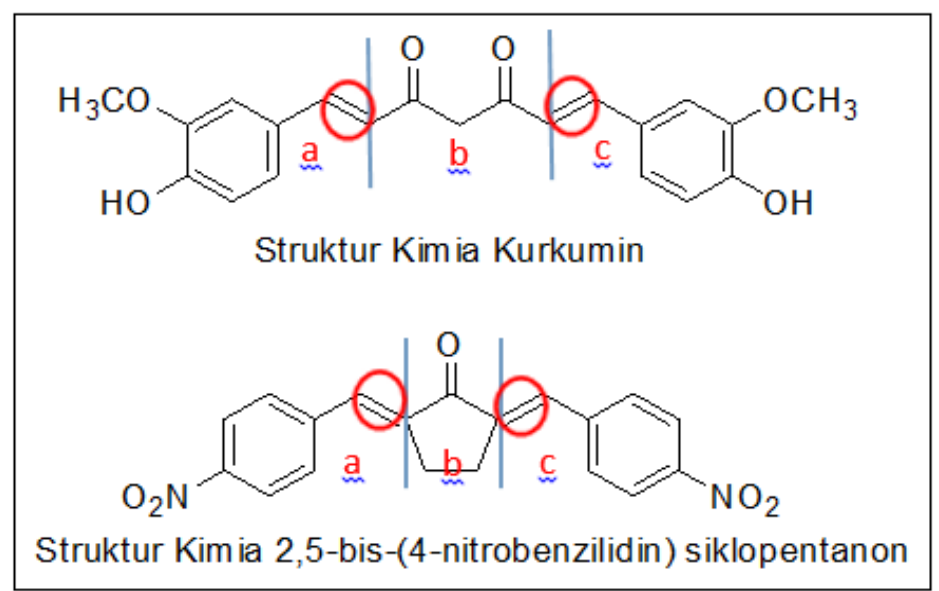

Gambar 1. Perbedaan Struktur Kimia Kurkumin dan 2,5-bis-(4-nitrobenzilidin) siklopentanon (Octasari dan Djunarko, 2012; Tonnesen dan Karlsen, 1985; Tonnesen dkk, 1986; Robinson dkk, 2003)

Pengolahan nilai AUC menjadi dasar bagi perhitungan daya antiinflamasi senyawa uji. Nilai AUC yang semakin kecil menunjukan bahwa kemampuan menurunkan edema lebih baik. Nilai AUC berbanding terbalik dengan persentase daya antiinflamasi senyawa uji. Persentase daya antiinflamasi yang didapatkan dianalisis menggunakan T-test guna membandingkan hasil daya antiinflamasi kedua kelompok senyawa uji, baik salep maupun krim senyawa uji 0,25\%. Hasil persentase daya antiinflamasi dapat dilihat pada tabel II.

Tabel II. Uji T-test Persentase Daya Antiinflamasi

\begin{tabular}{|c|c|c|}
\hline \multicolumn{2}{|c|}{ Persentase Daya Antiinflamasi (\%) } & \multirow{2}{*}{$\begin{array}{c}\text { Nilai p pada } \\
\text { Uji T-Test }\end{array}$} \\
\hline Krim Senyawa Uji 0,25\% & Salep Senyawa Uji 0,25\% & \\
\hline 25,849 & 44,746 & \multirow{6}{*}{$0.000 *$} \\
\hline 33,669 & $\mathbf{4 7 , 4 6 4}$ & \\
\hline 42,526 & 46,105 & \\
\hline 55,246 & $\mathbf{5 4 , 2 5 7}$ & \\
\hline 64,197 & 47,917 & \\
\hline$X=44,297$ & $X=48,098$ & \\
\hline
\end{tabular}

*berbeda signifikan

Berdasarkan tabel II, menunjukkan bahwa basis sediaan topikal berpengaruh terhadap daya antiinflamasi senyawa uji. Hasil analisis statistik menunjukkan bahwa basis salep menunjukkan daya antiinflamasi yang lebih besar dibandingkan basis krim. Kedua basis sediaan topikal tersebut memiliki persamaan, yaitu baik basis salep maupun basis krim yang digunakan adalah golongan basis hidrokarbon. Basis salep vaselin flavum dan basis krim setaseum merupakan basis yang berbahan dasar lemak. Bahan dasar lemak akan meningkatkan kelarutan bahan aktif yang bersifat lipofil seperti kurkumin dan senyawa uji. Pembawa yang bersifat lemak juga dapat digunakan sebagai penutup oklusif yang menghambat penguapan kelembaban kulit (Lachman dkk., 1994) sehingga dapat meningkatkan lama kontak zat aktif terhadap kulit (Ansel, 1989). Akan tetapi, terdapat perbedaan konsistensi antara setaseum dan vaselin flavum. Setaseum 
memiliki konsistensi yang lebih padat dibandingkan vaselin flavum. Peningkatan konsistensi yang sangat tinggi akan menyebabkan terhambatnya pelepasan zat aktif dari bahan pembawa menuju ke kulit sehingga berdampak pada kemampuan zat aktif terpenetrasi ke dalam sirkulasi sistemik. Oleh karena itu, sediaan salep senyawa uji memiliki daya antiinflamasi yang lebih besar dibandingkan sediaan krim yang memiliki konsistensi lebih padat.

Penelitian ini menunjukkan hasil yang sesuai dengan penelitian - penelitian sebelumnya yang menunjukkan aktivitas farmakologi senyawa kurkumin dan analognya. Pemberian kurkumin secara topikal dapat menghilangkan rasa nyeri dan eritema pada kejadian mastitis ibu menyusui secara uji RCT double blind (Afshariani dkk., 2014). Pemberian gel kurkumin menghambat inflamasi psoriasis yang diinduksi oleh imiquimod pada telinga hewan uji BALB/c (Sun dkk., 2013). Pemberian kurkumin secara transdermal juga memiliki efek pada proses penyembuhan luka (Lopez-Jornet dkk., 2011) dan kemopreventif pada kanker kulit.

\section{Kesimpulan}

Bentuk sediaan berpengaruh terhadap daya antiinflamasi $(\mathrm{p}<0.05)$. Persentase daya antiinflamasi salep 2,5-bis-(4-nitrobenzilidin) siklopentanon memiliki nilai lebih besar dibandingkan bentuk sediaan krim $(48,098 \pm 1,637)$.

\section{Ucapan Terimakasih}

Penelitian ini merupakan penelitian hasil kompetisi internal Perguruan Tinggi yang didanai oleh Yayasan Bernardus Sekolah - Sekolah Theresiana Semarang. 


\section{Daftar Pustaka}

Anand, Sundaram, Jhurani, Kunnumakkara dan Anggarwal. 2008. Curcumin and Cancer: An OldAge Disease with an Age-Old Solution. Cancer Letter. 1 (267) : 133-164.

Ansel, H.C., 1989. Pengantar Bentuk Sediaan Farmasi Edisi IV. Jakarta: Universitas Indonesia Press.

Araujo, dan Leon. 2001. Biological Activities of Curcuma longa L. MemInst Oswaldo Cruz, Rio de Janeiro. 96 (5): 723-728.

Afshariani, R., Farhadi, P., Ghaffarpasand, F., and Roozbeh, J., 2014., Effectiveness of Topical Curcumin for Treatment of Mastitis in Breastfeeding Women: A Randomized, Double-Blind, Placebo-Controlled Clinical Trial, Oman Medical Journal, Vol. 29, No. 5:330-334.

Budiarti, T., Suzana, dan Surdijati, S., 2010. Sintesis, Uji Aktivitas Analgesik dan Antiinflamasi Senyawa Benzoiltiourea Tersubstitusi. Majalah Farmasi Indonesia, 21 (2), 68-76.

Cannon, K.E., Leurs R., and Hough L.B., 2007. Activation of Peripheral and Spinal Histamine $\mathrm{H}_{3}$ Receptors Inhibits Formalin-Induced Inflammation and Nociception, Respetively. Pharmacol Biochem Behav., 88 (1), 122-129.

Chainani-Wu, N., 2003. Safety and Anti-inflamatory Activity of Curcumin: A Component of Tumeric (Curcuma Longa). The Journal of Alternative and Complementary Medicine, 9 (1), 161-168.

Gunani, S. B., 2009, Uji Daya Antiinflamasi Krim Tipe A/M Ekstrak Etanolik Jahe 10\% (Zingiberofficinale Roscoe) yang Diberikan Topikal Terhadap Udem Kaki Tikus yang Diinduksi Karagenin, LaporanPenelitian, Surakarta.

Itokawa, H., Shi, Q., Akiyama, T., Morris-Natschke, S.L., \& Lee, K.H., 2008. Review: Recent Advances In The Investigation Of Curcuminoids. BioMed Central [online]. Dapat dilihat pada: http://www.cmjournal.org/ [diakses pada 1 Mei 2016].

Jayaprakasha, G, K., Jagan Mohan Rao dan Sakariah, K, K., 2006. Antioxidant Activities of Curcumin, Demethoxycurcumin and Bisdemethoxycurcumin. Food Chemistry. 98, 720-724.

Katzung, G.B., 2002. Farmakologi Dasar dan Klinik, Edisi 8. Jakarta: Salemba Medika.

Kee. J. L. and Hayes. E. R, 1996, FarmakologiPendekatan Proses Keperawatan, edisi 5, diterjemahkan Peter. A., 310-317, BukuKedokteran EGC, Jakarta.

Lopez-Jornet P, Camacho-Alonso F, Jimenez-Torres MJ, Orduna-Domingo A, Gomez-Garcia F. 2011. Topical curcumin for the healing of carbon dioxide laser skin wounds in mice. Photomed Laser Surg. 29:809-14.

Majeed, M., Badmaev, V., Shivakumar, U., and Rajendran, R., 1995. Curcuminoids Antioxidant Phytonutrients. United States Of America: Nutriscience Publisher Piscataway.

Niazi, P.P., Vikas, G., and Narinderpal K., 2010. Pharmacotherapeutics Of Curcuma Longa-A Potent Patent, International Journal Of Pharma Professional's Research. 1: 24-30.

Nurrochmad, A., 1997, Penghambatan Biosintesis Prostaglandin Melalui Jalur Siklooksigenase oleh Siklovalon dan Tiga Senyawa Analognya, Skripsi, Fakultas Farmasi Universitas Gadjah Mada, Yogyakarta

Octasari, P.M., dan Djunarko, I., 2012. Efek Anti-Inflamasi Benzoil Eugenol secara Topikal terhadap Edema Kaki yang Diinduksi Formalin 0,5\% pada Mencit Jantan Galur Swiss. Jurnal Farmasi Sains dan Komunitas, 9 (1), 26-35. 
Pandey, and Sanjay, K., 2010. Determination and Comparison of The Curcuminoid Pigments in Tumeric Genotypes (Curcuma Domestica Val) by Highperformance Liquid Chromatography, International Journal of Pharmacy and Pharmaceutical Sciences. 2 (4): 125-127.

Rhen, T. dan Cidlowski J.A., 2005. Antiinflammatory action of glucocorticoids-new mechanisms for old drugs. $N$ Engl J Med, No. 353. Dapat dilihat pada: http://www.nejm.org/ [Diakses pada 20 Desember 2014].

Robinson, T., Ehlers, R.B., Hubbard, X., Bai, J.L., Arbiser, D.J., Goldsmith, J.p., Bowen. 2003. Design, Synthesis and Biological Evaluation Of Aromatic Enones, Related to Curcumin, Bioorg. Med. Chem. Let.13, 115-117.

Sopiyudin, M.D., 2014. Statistik Untuk Kedokteran Dan Kesehatan, Seri 1 edisi 6. Jakarta: Epidemiologi Indonesia

Sun J, Zhao Y, Hu J. 2013. Curcumin inhibits imiquimod-induced psoriasis-like inflammation by inhibiting IL-1beta and IL-6 production in mice. PLoS One. 8:e67078.

Tonnesen, H. H. dan Karlsen, J., 1985. Studies of Curcumin and Curcuminoids: VI. Kinetics of Curcumin Degradation in Aqueous Solutions. Z. Lebensm.Unters. Forsch, 180(5), 402-4. Dapat dilihat pada: http://www.ncbi.nlm.nih.gov/ [Diakses pada 20 Desember 2014].

Tonnesen, H. H., Karlsen, J., dan Van Henegouwen G.B., 1986. Studies of Curcumin and Curcuminoids: VIII. Photochemical stability of Curcumin. Z. Lebensm.Unters. Forsch, 183(2), 116-22. Dapat dilihat pada: http://www.ncbi.nlm.nih.gov/ [Diakses pada 20 Desember 2014].

Widyastani, F.A. dan Hariono, M., 2013. Synthesis of 2,5-bis-(4-nitrobenzilydene) cyclopentanone via Claisen Schmidt Condensation Reaction. Prosiding Seminar Internasional. Yogyakarta: Universitas Gadjah Mada. 